\title{
Simvastatin Attenuates Neurogenetic Damage and Improves Neurocongnitive Deficits Induced by Isoflurane in Neonatal Rats
}

\author{
Ning Wanga Yang Lu ${ }^{a} \quad$ Kui Wang ${ }^{a}$ Wei-song Lia Pan Lu ${ }^{a} \quad$ Shan Leia \\ Rong Lia Hong Zhang ${ }^{a}$ Juan Zheng ${ }^{a}$ Hai-xia Lu ${ }^{b}$ Xin-lin Chen ${ }^{b}$ \\ Yong Liub Peng-bo Zhang ${ }^{\mathrm{a}}$ \\ aDepartment of Anesthesiology, The Second Affiliated Hospital of Xi'an Jiaotong University, Shaanxi, \\ ${ }^{b}$ Institute of Neurobiology, National Key Academic Subject of Physiology of Xi'an Jiaotong University, \\ Shaanxi, China
}

\section{Key Words}

Simvastatin • Isoflurane $・$ Neural stem cells $•$ Akt $•$ GSK-3 3 • Caspase-3

\begin{abstract}
Background/Aims: Isoflurane inhibited neurogenesis and induced subsequent neurocognitive deficits in developing brain. Simvastatin exerts neuroprotection in a wide range of brain injury models. In the present study, we investigated whether simvastatin could attenuate neurogenetic inhibition and cognitive deficits induced by isoflurane exposure in neonatal rats. Methods: Sprague-Dawley rats at postnatal day (PND) 7 and neural stem cells (NSCs) were treated with either gas mixture, isoflurane, or simvastatin 60 min prior to isoflurane exposure, respectively. The rats were decapitated at PND 8 and PND 10 for detection of neurogenesis in the subventricular zone (SVZ) and subgranular zone (SGZ) of the hippocampus by immunostaining. NSC proliferation, viability and apoptosis were assessed by immunohistochemistry, CCK-8 and TUNEL, respectively. The protein expressions of caspase-3, p-Akt and p-GSK-3 $\beta$ both in vivo and vitro were assessed by western blotting. Cognitive functions were assessed by Morris Water Maze test and context fear conditioning test at the adult. Results: Isoflurane exposure inhibited neurogenesis in the SVZ and SGZ, decreased NSC proliferation and viability, promoted NSC apoptosis and led to late cognitive deficits. Furthermore, isoflurane increased caspase- 3 expression and decreased protein expressions of $p$-Akt and $p-G S K-3 \beta$ both in vivo and in vitro. Pretreatment with simvastatin attenuated isoflurane-elicited changes in NSCs and cognitive function. Co-treatment with LY294002 reversed the effect of simvastatin on NSCs in vitro. Conclusion: We for the first time showed that simvastatin, by upregulating Akt/GSK-3 $\beta$ signaling pathway, alleviated isoflurane-induced neurogenetic damage and neurocognitive deficits in developing rat brain.
\end{abstract}




\section{Cellular Physiology Cell Physiol Biochem 2018;46:618-632 \begin{tabular}{l|l} 
DOI: 10.1159/000488630 & and Biochemistry \\
Published online: April 04, 2018 & $\begin{array}{l}\text { O } 2018 \text { The Author(s). Published by S. Karger AG, Basel } \\
\text { www.karger.com/cpb }\end{array}$
\end{tabular}}

Wang et al.: Developmental Neurotoxicity and Neuroprotection

\section{Introduction}

Every year millions of children undergo anesthesia for surgical procedures. However, increasing experimental data in neonatal rodents and nonhuman primates settings have shown that early exposure to commonly used general anesthetics impaired brain development such as inhibiting neurogenesis, inducing widespread neuroapoptosis and longterm neurocognitive deficits [1-3]. Epidemiological studies indicated that young children underwent general anesthesia were possibly associated with potential neurocognitive impairment later in life [4-8]. Although numerous studies have focused on anesthesia-induced neurocognitive impairment, it is still important and imperative to explore the mechanisms of anesthesia-induced neurocognitive impairment and develop potential protective strategies.

One important stage of brain development for rodents and humans is called brain growth spurt (BGS), in which neural stem cells proliferate, differentiate, and migrate abundantly in the brain. The characteristics of BGS make the developing brain more vulnerable to exogenous insults. In humans, BGS period extends from about third trimester to two years after birth. In rodents, BGS lasts from birth for the first 2 weeks of life [9]. There is a reasonable amount of evidence to support the hypothesis that volatile anesthetics exposure during early postnatal development causes impairments in neurogenesis [10]. It was speculated that progressive decline in cognitive function is a consequence of an early loss or suppression of pool of rapidly dividing, multipotent precursors, which might create an ongoing deficit in neurogenesis that worsened over time as the gap in NSC numbers between normal controls and exposed animals widened with rapid cell division [11]. Recently, we reported that pretreatment with minocycline restored neurogenesis in the subventricular zone (SVZ) and subgranular zone (SGZ) of the hippocampus and improved adult spatial learning and memory deficits induced by ketamine exposure in neonatal rats [12]. Thus, the prevention of neurogenesis inhibition might be a new effective therapeutic approach for anesthetic-induced neurocognitive impairment in the developing brain.

Isoflurane, a typical volatile anesthetic, increased immediately neuroapoptosis in postnatal animals. It induced more profound apoptosis than sevoflurane did at equivalent dose [13]. Repeated or longer exposure to isoflurane induces greater longmemory impairment than desflurane [14]. It has been identified that isoflurane decreases hippocampal neurogenesis in neonatal rat and impaired NSC proliferation in vitro [15-18]. However, whether attenuation of neurogenetic damage induced by isoflurane contributes to improvement of neurocognitive deficits remains unknown.

Besides cholesterol-lowering effects, simvastatin, a HMG-CoA reductase inhibitor, is known as its neuroprotection in several brain injury models such as brain ischemia, traumatic brain injury, experimental intracerebral hemorrhage, and subarachnoid hemorrhage [19$23]$ and it has no significant toxicity effects in neonatal rats [24, 25]. Its therapeutic effect might be mediated by reducing vasospasm, oxidative stress, inflammation and apoptosis, promoting angiogensis and neurogenesis, restoring endothelial function and activating phosphoinositide 3-kinase (PI3K)/Akt/glycogen synthase kinase-3beta (GSK-3 $\beta$ ) signaling pathway $[23,26]$. However, whether simvastatin can protect the developing brain from isoflurane-induced neurogenetic damage and improve neurocognitive deficits remains to be elucidated.

In this study, we investigated whether simvastatin could restore neurogenesis and improve neurocognitive deficits following isoflurane exposure. We further explored whether PI3K/Akt/GSK-3 $\beta$ signaling pathway was involved in the neuroprotective effect of simvastatin.

\section{Materials and Methods}

Animal Protocols

All experimental protocols and animal handling procedures were performed in accordance with the National Institute of Health Guide for the Care and Use of Laboratory Animals (NIH Publications No. 80-23) 


\section{Cellular Physiology Cell Physiol Biochem 2018;46:618-632 and Biochemistry Published online: April 04, $2018 \quad \begin{aligned} & \text { DOI 10159/2018 The Author(s). Published by S. Karger AG, Basel } \\ & \text { www.karger.com/cpb }\end{aligned}$}

Wang et al.: Developmental Neurotoxicity and Neuroprotection

revised in 1996 and the experimental protocols were approved by Ethics Committee on Animal Care of Xi'an Jiaotong University for animal welfare. 7-day-old (PND 7) and embryonic day 18-19 Sprague-Dawley rats were obtained from Laboratory Animal Centre of Xi'an Jiaotong University. Animal procedures were designed to minimize the number of animals used. We used both female and male rat pups but did not assess potential sex differences in the present studies.

\section{Isoflurane Exposure in vivo and Tissue Preparation}

PND 7 rats weighing 17-20 g were randomly divided into three groups (45 rats in each group): control group (Ctrl), isoflurane group (Iso) and simvastatin pretreatment group (Iso+simva), respectively. PND 7 rats in both isoflurane group and simvastatin pretreatment group were exposed initially to 3.4\% isoflurane (Lunan Bert Pharmaceutical Group Corporation, Shanghai, China) in $2 \mathrm{~L} \mathrm{~min}^{-1}$ of gas mixture $\left(50 \% \mathrm{O}_{2}\right.$ and $50 \% \mathrm{~N}_{2}$ ) and subsequently 1 minimum alveolar concentration (MAC) for $6 \mathrm{~h}$ as described previously [18]. The rats in control group received the gas mixture without isoflurane. PND 7 rats in simvastatin pretreatment group received subcutaneously $2 \mathrm{mg} \mathrm{kg}^{-1}$ simvastatin ( $5 \mathrm{ml} \mathrm{kg}^{-1}$, Selleck Chemicals Inc. Houston, TX, USA) 60 min before isoflurane exposure. PND 7 rats in control group and isoflurane group received subcutaneously $\left(5 \mathrm{ml} \mathrm{kg}^{-1}\right)$ normal saline $60 \mathrm{~min}$ before exposure. All animals were kept in an anesthetic chamber with a heating pad at the bottom to maintain normothermia, which was detected at 15 min intervals. Respiratory rate, shin color and body movement were observed carefully. The infant pulse oximetry probe was attached to the abdomen of the anesthetized pups to monitor pulse oxygen saturation $\left(\mathrm{SpO}_{2}\right)$. The concentrations of isoflurane, $\mathrm{CO}_{2}, \mathrm{O}_{2}$ and $\mathrm{N}_{2}$ were continuously monitored by a gas analyzer (Drager Inc., German).

The rat pups (10 rats in each group, $\mathrm{n}=5$ for each time point) received $50 \mathrm{mg} \mathrm{kg} \mathrm{g}^{-1} 5$-Bromo-2'deoxyuridine (BrdU, Sigma-Aldrich Inc. St. Louis, Mo, USA) intraperitoneally at the beginning and $4 \mathrm{~h}$ after isoflurane exposure, respectively. At 24 and $72 \mathrm{~h}$ after anesthesia, they were anesthetized with pentobarbital sodium (100 mg kg-1) and transcardially perfused by $0.9 \%$ saline, followed by cold $4 \%$ paraformaldehyde in PBS. The brain tissue from bregma $+0.2 \mathrm{~mm}$ to bregma $-6.0 \mathrm{~mm}$ was removed and postfixed in $4 \%$ paraformaldehyde overnight at $4{ }^{\circ} \mathrm{C}$, then dehydrated in $30 \%$ sucrose solution for 3-4 days. The coronal sections of the brain $(16 \mu \mathrm{m})$ were cut by freezing microtome (SLEE, Germany). For western blotting, rat pups ( 15 rats for each group, $n=5$ for each time point) were sacrificed by decapitation at 0,6 and $12 \mathrm{~h}$ after isoflurane exposure. SVZ and SGZ were isolated immediately on ice and the stored at $-80^{\circ} \mathrm{C}$ until used. The rest rat pups (20 rats for each group, $n=10$ for each behavior study) were transferred to their cages after exposure for behavior study at the adult. The rats were separated according to gender on PND 21.

\section{Cell Culture and Isoflurane Exposure}

Rat primary NSC cultures were prepared from the dissected cortex of 30 Sprague-Dawley rats in 18-19 days of gestation under sterile condition. Briefly, the forebrain portion was dissected and placed in ice-cold Hank's solution (without $\mathrm{Mg}^{2+}$ and $\mathrm{Ca}^{2+}$, Gibco, Carlsbad, CA, USA). The cells were dissociated by mechanical agitation through a fire-polished Pasteur pipette. After centrifugation, the isolated cells were resuspended in free-serum DMEM/F12 medium (Gibco, Carlsbad, CA, USA) which was supplemented with 2\% B27 (Gibco, Carlsbad, CA, USA), $20 \mathrm{ng} \mathrm{ml}^{-1}$ EGF (Gibco, Carlsbad, CA, USA), 20ng ml-1 bFGF (Gibco, Carlsbad, CA, USA), and $100 \mathrm{U} \mathrm{ml}^{-1}$ penicillin and phytomycin. A half of culture medium was replaced every 3 days. According to the neurosphere method developed by Reynolds and Weiss [27], cells were incubated for 7 days to form enough neurospheres. Then the cells were passaged at a density of $2 \times 10^{5} \mathrm{cells} \mathrm{ml}^{-1}$ followed by collection and dissociation. The medium was changed every 3 days. After the second passage, nestin-positive NSCs were enriched in neurospheres with minimal presence of differentiated cells ( $\beta$-tubulin $\amalg$, or glial fibrillary acidic protein (GFAP)-positive cells), which indicating the characteristic of the NSC preparation. For identification of NSC differentiation, after passage, the dissociated cells were seeded onto $100 \mu \mathrm{g} \mathrm{ml}^{-1} \mathrm{poly}^{-}$ L-lysine-coated coverslips and incubated with differentiating medium which contains 100× N2 supplement, $100 \times$ B27 supplement and 1\% fetal bovine serum (FBS, Gibco, Carlsbad, CA, USA) in DMEM/F12 (without b-FGF). At the end of 7 day's culture, the cells were processed for differentiation analysis. A total of 5-7 randomly selected images were captured in each well, and the number of cells expressing $\beta$-tubulin III, GFAP tested by $\beta$-tubulin III antibody (Sigma-Aldrich Inc. St. Louism, MO, USA) and GFAP antibody (Sigma-Aldrich Inc. St. Louism, MO, USA) were counted (at least 200 cells per test case), and data were collected from 3 independent experiments.

\section{KARGER}




\section{Cellular Physiology Cell Physiol Biochem 2018;46:618-632

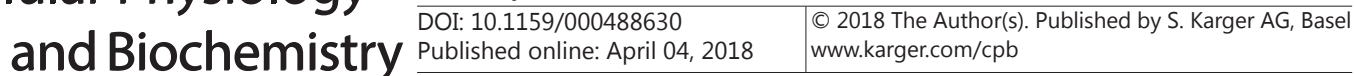

Wang et al.: Developmental Neurotoxicity and Neuroprotection

Isoflurane exposure procedure was established as described previously [16]. NSC cultures received with or without $3.4 \%$ isoflurane in a gas mixture $\left(5 \% \mathrm{CO}_{2}, 21 \% \mathrm{O}_{2}\right.$ and $\left.74 \% \mathrm{~N}_{2}\right)$ at $37^{\circ} \mathrm{C}$ in a tightly sealed plastic chamber. Simvastatin (Selleck Chemicals Inc. Houston, TX, USA) was activated before use as described [28]. For in vitro investigation, $0.1 \mu \mathrm{M}$ simvastatin or equivalent volume of PBS was administrated to the NSC cultures 60 min before isoflurane exposure [29]. For PI3K pathway analysis, $10 \mu \mathrm{M}$ LY294002 (Cell Signal Technology Inc. Beverly, MA, USA) or equivalent volume of PBS was added into NSC cultures $2 \mathrm{~h}$ before isoflurane exposure.

\section{Immnofluorescence Staining}

To investigate neurogenesis in SVZ and SGZ, the sections were incubated in $2 \mathrm{~N} \mathrm{HCl}$ for 30 min at $37^{\circ} \mathrm{C}$ for denaturation of the DNA, then the sections were rinsed in $0.1 \mathrm{~mol} \mathrm{~L}^{-1}$ boric acid (pH 8.5) for $10 \mathrm{~min}$ at room temperature, rinsed 3 times with $0.1 \mathrm{M}$ PBS for $10 \mathrm{~min}$. Then sections were incubated in blocking solution (2\% goat serum and $0.3 \%$ Triton $\mathrm{X}-100)$ for $2 \mathrm{~h}$ at room temperature. Sections were incubated overnight at $4{ }^{\circ} \mathrm{C}$ with the primary antibodies: mouse monoclonal anti-BrdU antibody (1:200, Abcam, UK), rabbit monoclonal anti-nestin antibody (1:200; Sigma-Aldrich Inc. St. Louis, MO, USA), rabbit monoclonal anti- $\beta$-tubulin III antibody (1:500; Sigma-Aldrich Inc. St. Louis, MO, USA), and rabbit monoclonal anti-glial fibrillary acidic protein (GFAP) antibody (1:500; Sigma-Aldrich Inc. St. Louis, MO, USA). After 3 washes with $0.1 \mathrm{M}$ PBS, the sections were incubated with suitable secondary antibodies (1:200, cy3 anti-mouse and fluorescein isothiocyanate (FITC) anti-rabbit) for $2 \mathrm{~h}$ at room temperature. Sections were incubated with PBS instead of the primary antibodies as negative controls. Nestin/BrdU, $\beta$-tubulin III/BrdU, GFAP/ BrdU-positive cells were counted within defined regions of interest in the SVZ and SGZ. In total, six $16 \mu \mathrm{m}$ coronal sections, spaced approximately $200 \mu \mathrm{m}$ apart, were examined per animal. Fluorscence images were obtained by fluorescence microscopy (BX51, Olympus, Tokyo, Japan). In each section, measurements were performed in 5 regions, and planar area enclosed by each region was $50 \mu \mathrm{m} \times 50 \mu \mathrm{m}$. The edges of the regions were defined based on structural details within the tissue section to ensure that fields did not overlap [30]. The density of positive cells was presented as the total number of positive cells within the SVZ and SGZ. The purpose of quantification was not to estimate the total number, but to obtain a count within the studied regions to compare between different groups.

To evaluate NSC proliferation in vitro, the passaged cells were seeded onto $100 \mu \mathrm{g} \mathrm{ml}^{-1}$ poly-L-lysinecoated cover slips and incubated with BrdU $\left(10 \mu \mathrm{mol} \mathrm{L}^{-1}\right)$ for $4 \mathrm{~h}$. Before staining with BrdU antibody and propidium iodide (PI), cells were fixed with 4\% paraformaldehyde for $20 \mathrm{~min}$. Immunoreactive cells were visualized by fluorescence microscopy and a total of 5-7 randomly selected fields were captured. At least 200 cells were counted each condition, and data were collected from 3 independent experiments.

\section{Cell viability test}

Cell viability was determined by the cell counting kit-8 (CCK-8). In brief, after passage, the cells were seeded in 96-well plates at a density of 5000 cells per well. After treatments, $10 \mu \mathrm{l}$ CCK-8 solutions was added to each well and incubated for $4 \mathrm{~h}$. The Optical density value (OD) at wavelength $450 \mathrm{~nm}$ was measured using a microplate reader, and the value was corrected by subtracting the absorbance of control wells that did not contain cells. Data were collected from 3 independent experiments.

\section{Cell apoptosis test}

Cell apoptosis was determined by the terminal dUTP nick-end Labeling (TUNEL) assay. Briefly, after passage, the dissociated cells were seeded onto $100 \mu \mathrm{g} \mathrm{ml}^{-1}$ poly-L-lysine-coated cover slips. Cells were fixed with $4 \%$ paraformaldehyde at 12,24 and $48 \mathrm{~h}$ after isoflurane exposure. The TUNEL assay was performed according to the instruction of in situ cell death detection Kit (Roche Inc. Roche, Mannheim, Germany) to identify cell apoptosis. Data were collected from 3 independent experiments.

\section{Western blot Analysis}

Tissue from the SVZ and SGZ of hemispheres and cell cultures were lysed with RIPA lysis buffer containing protease and phosphatase inhibitors. The lysates were placed on ice for $15 \mathrm{~min}$ and centrifuged at $14000 \mathrm{rpm}$ for $15 \mathrm{~min}$ at $4^{\circ} \mathrm{C}$. Protein concentrations in the resulting lysates were determined by the BCA protein assay kit, bovine serum albumin (BSA) was used as a standard. Equal amount of the resulting lysate was resolved by sodium dodecyl sulfate-polyacrylamide gel and the separated proteins were 


\section{Cellular Physiology Cell Physiol Biochem 2018;46:618-632

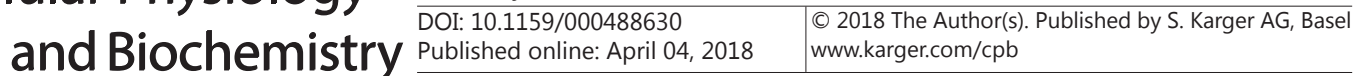

Wang et al.: Developmental Neurotoxicity and Neuroprotection

transferred to polyvinylidene fluoride membranes. The membranes were incubated with blocking buffer for $1 \mathrm{~h}$ at room temperature and then incubated overnight at $4^{\circ} \mathrm{C}$ with primary antibodies: caspase- 3 (cleaved, 17KDa, 1:1000, Cell Signal Technology Inc. Beverly, MA, USA), phosohorylated Akt (p-Akt, 1:1000, Cell Signal Technology Inc. Beverly, MA, USA), Akt (1:1000, Cell Signal Technology Inc. Beverly, MA, USA), phosophorylated GSK-3 $\beta$ (p-GSK-3 $\beta, 1: 1000$, Cell Signal Technology Inc. Beverly, MA, USA), GSK-3 $\beta$ (1:1000, Cell Signal Technology Inc. Beverly, MA, USA) and $\beta$-actin (1:1000, Cell Signal Technology Inc. Beverly, MA, USA). The signals were detected using goat anti-rabbit or anti-mouse horseradish peroxidase-conjugated secondary antibody and enhanced chemiluminescence (ECL), then exposed to X-ray films. Blots were quantified using analysis system and all data from 3 independent experiments were expressed as the ratio to optical density (OD) values of the corresponding controls.

\section{Morris Water Maze (MWW) Test}

The spatial learning and memory ability of rats underwent isoflurane exposure at PND 7 was measured using MWM test as described previously [31] with some modifications. Briefly, PND 42 rats of each group were trained for place trials and probe trials in a large tank $150 \mathrm{~cm}$ in diameter and $50 \mathrm{~cm}$ in depth, which was divided into four quadrants. And a hidden 10-cm-diameter and 30-cm-high platform, $1.5 \mathrm{~cm}$ below the surface of warm water was placed in the center of one quadrant. Milk powder was added into the water to cover the platform. The place trials were conducted 4 times daily at the same time point for 5 successive days and the probe trials were performed on the sixth day after the training. For place trials, rats were placed into four quadrants in order (spaced $20 \mathrm{~min}$ apart) to swim freely for a maximum of $120 \mathrm{~s}$. If the platform was not found, the rats were guided to the platform. The rat was allowed to stay at the platform for $20 \mathrm{~s}$ to observe the environment. The latency to find platform and swim speed were recorded. For probes trials, the platform was removed and the rats were put into the quadrant opposite to where the platform located and allowed to swim for $120 \mathrm{~s}$. The times of the rats crossing the platform were recorded.

\section{Context Fear Conditioning (CFC) Test}

The CFC test was performed as described previously [32,33] with modification on PND 55 rats which exposed to isoflurane at PND 7. Specifically, each rat was placed in a $40 \times 30 \times 26 \mathrm{~cm}$ pellucid perspex chamber which was in a $75 \times 60 \times 45 \mathrm{~cm}$ soundproof cabinet. A high resolution video camera was located on the ceiling of the cabinet to record the activity of each animal, and 30 iron bars were installed in the floor of the chamber to transmit a mild electric foot shock ( $0.8 \mathrm{~mA}$ for $1 \mathrm{~s})$. For the CFC training, each rat was allowed to explore in the chamber for $120 \mathrm{~s}$ and then received an immediate foot shock. The training was performed 4 times with 2 min intervals. The CFC testing was performed $24 \mathrm{~h}$ later. Each rat was placed into the same chamber and stay for a total $360 \mathrm{~s}$, and the ratio of freezing time the rat demonstrated "freezing behavior" during the second $180 \mathrm{~s}$ was measured to assess cognitive function. Freezing behavior was defined as a completely immobile posture except respiratory efforts.

\section{Statistical analysis}

Data were expressed as the mean \pm SEM. Differences between the groups were analyzed by one-way analysis of variance (ANOVA) followed by the post-hoc Duncon's test. Data from escape latency in the Morris water maze place trials were analyzed using two-way repeated measures ANOVA followed by post-hoc Tukey test to indicate the interaction between treatment and time as well as the differences between three individual groups. Data analysis were generated using SPSS for Windows version 19.0 (USA) and Prism 5 software (GraphPad, USA). Statistical significance was set at $P<0.05$.

\section{Results}

Simvastatin restored neurogenesis and reduced cell apoptosis in SVZ and SGZ following isoflurane exposure

The number of nestin ${ }^{+} / \mathrm{BrdU}^{+}$cells in isoflurane group decreased significantly both in the SVZ and SGZ compared with that in control group $24 \mathrm{~h}$ after isoflurane exposure. The suppressive effect of isoflurane on NSC proliferation was also found at $72 \mathrm{~h}$ after isoflurane exposure. On the contrary, simvastatin increased the number of nestin ${ }^{+} / \mathrm{BrdU}^{+}$cells in both 


\section{Cellular Physiology and Biochemistry

two regions at 24 and $72 \mathrm{~h}$ after isoflurane exposure compared with the isoflurane group. These data indicated that simvastatin increased the proliferation of NSCs in the SVZ and SGZ in neonatal rats (Fig. 1).

The phenotype of newly generated cells in the SVZ and SGZ were detected by immunohistochemistry. It was shown that the number of $\beta$-tubulin $\mathrm{III}^{+} / \mathrm{BrdU}^{+}$ cells, a marker for newborn neurons, in isoflurane group was decreased both in the SVZ and SGZ compared to that in the control group at 24 and $72 \mathrm{~h}$ after isoflurane exposure, respectively. Pretreatment with simvastatin significantly increased the number of $\beta$-tubulin $\mathrm{III}^{+} / \mathrm{BrdU}^{+}$cells (Fig. 2), marker for newborn neurons. Compared with the control group, the number of $\mathrm{GFAP}^{+} / \mathrm{BrdU}^{+}$ cells, marker for newborn astrocytes, deceased in isoflurane group both in the SVZ and SGZ at $24 \mathrm{~h}$ after anesthesia, respectively. However, the number of $\mathrm{GFAP}^{+} / \mathrm{BrdU}^{+}$cells was increased in both two regions after simvastatin pretreatment. Interestingly, the inhibitory effect of isoflurane on astrocyte differentiation of NSCs was not observed at $72 \mathrm{~h}$ after the anesthesia, and there was no difference among three groups (Fig. 3).

Regarding to the major role of caspases in neural stem/progenitor cell (NSPC) apoptosis [34], the protein expression of caspase-3 in the SVZ and SGZ 12h after isoflurane exposure was detected by Western blotting to determine NSPC apoptosis. Compared with the control group, in which the expression level of caspase-3 was relatively low, isoflurane exposure increased the caspase-3 expression
Fig. 1. The number of nestin ${ }^{+} / \mathrm{BrdU}^{+}$cells in the SVZ and SGZ. (A, B) Representative double immnofluorenscence images of nestin ${ }^{+} / \mathrm{BrdU}^{+}$cells in the SVZ and SGZ $24 \mathrm{~h}$ after isoflurane exposure, respectively. Cells were stained for nestin (green) and BrdU (red). (C, D) Quantitative analysis of nestin ${ }^{+}$/ $\mathrm{BrdU}^{+}$positive cells in the SVZ and SGZ at different times after isoflurane exposure, respectively. All data are presented as mean \pm SEM. $\mathrm{n}=5$ for each group. ${ }^{* *} \mathrm{P}<0.01$ vs. control; \#\#P<0.01 vs. Iso group. Scale bar $=100 \mu \mathrm{m}$. LV: Lateral Ventricle.

Fig. 2. The number of $\beta$-tubulin $\mathrm{III}^{+} / \mathrm{BrdU}^{+}$cells in the SVZ and SGZ. $(A, B)$ Representative double immnofluorenscence images of $\beta$-tubulin $\mathrm{III}^{+}$/ $\mathrm{BrdU}^{+}$cells in the SVZ and SGZ $24 \mathrm{~h}$ after isoflurane exposure, respectively. Cells were stained for $\beta$-tubulin III (green) and BrdU (red). (C, D) Quantitative analysis of $\beta$-tubulin $\mathrm{III}^{+} / \mathrm{BrdU}^{+}$positive cells in the SVZ and SGZ at different times after isoflurane exposure, respectively. All data are presented as mean \pm SEM. $n=5$ for each group. ${ }^{* *} \mathrm{P}<0.01$ vs. control; $\# \mathrm{P}<0.05$, \#\#P<0.01 vs. Iso group. Scale bar $=100 \mu \mathrm{m}$. LV: Lateral Ventricle.
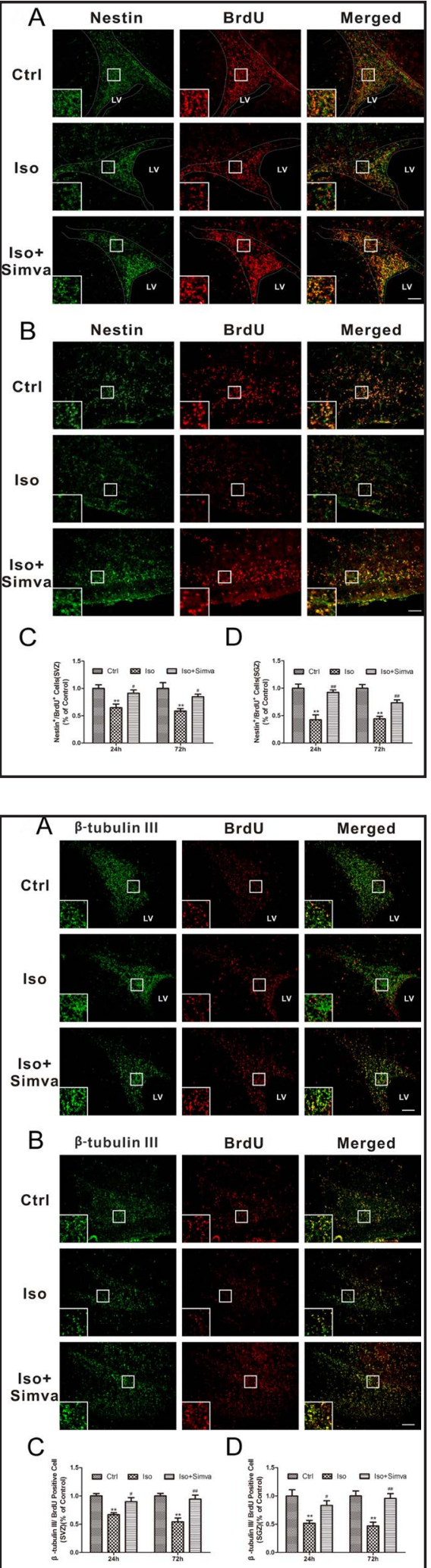
in the both regions. However, pretreatment with simvastatin decreased protein expression of caspase-3 in the SVZ and SGZ of isoflurane-treated neonatal rats (Fig. 4A, B).

As activating PI3K/Akt/GSK-3 $\beta$ cascade has been reported to inhibit apoptosis and promote cell survival through insulin and growth factors. The protein expressions of p-Akt and $\mathrm{p}$-GSK-3 $\beta$ in the SVZ and SGZ were examined by Western blotting. Compared with the control group, decreased protein expressions of p-Akt and p-GSK-3 $\beta$ were found significantly at 0,12 and $24 \mathrm{~h}$ after isoflurane exposure. However, pretreatment with simvastatin enhanced significantly the protein expressions of $\mathrm{p}$-Akt and p-GSK-3 $\beta$ which were deregulated by isoflurane in the both regions (Fig.4C, $\mathrm{D}, \mathrm{E}$, and F). There were no significant difference in total amount of Akt and GSK-3 $\beta$ in the both regions. These results indicated that enhancement of Akt and GSK-3 $\beta$ phosophorylation is associated with the simvastatin's neuroprotective effect against isoflurane-

Fig. 3. The number of $\mathrm{GFAP}^{+} / \mathrm{BrdU}^{+}$cells in the SVZ and SGZ. (A, B) Representative double immnofluorenscence images of $\mathrm{GFAP}^{+} / \mathrm{BrdU}^{+}$ cells in the SVZ and SGZ, $24 \mathrm{~h}$ after isoflurane exposure respectively. Cells were stained for GFAP (green) and BrdU (red). (C, D) Quantitative analysis of $\mathrm{GFAP}^{+} / \mathrm{BrdU}^{+}$ positive cells in the SVZ and SGZ at different times after isoflurane exposure, respectively. All data are presented as mean \pm SEM. $n=5$ for each group. $* \mathrm{P}<0.05, \quad{ }^{* *} \mathrm{P}<0.01 \quad$ vs. control; $\# \mathrm{P}<0.05$ vs. Iso group. Scale bar $=100 \mu \mathrm{m}$. LV: Lateral Ventricle.

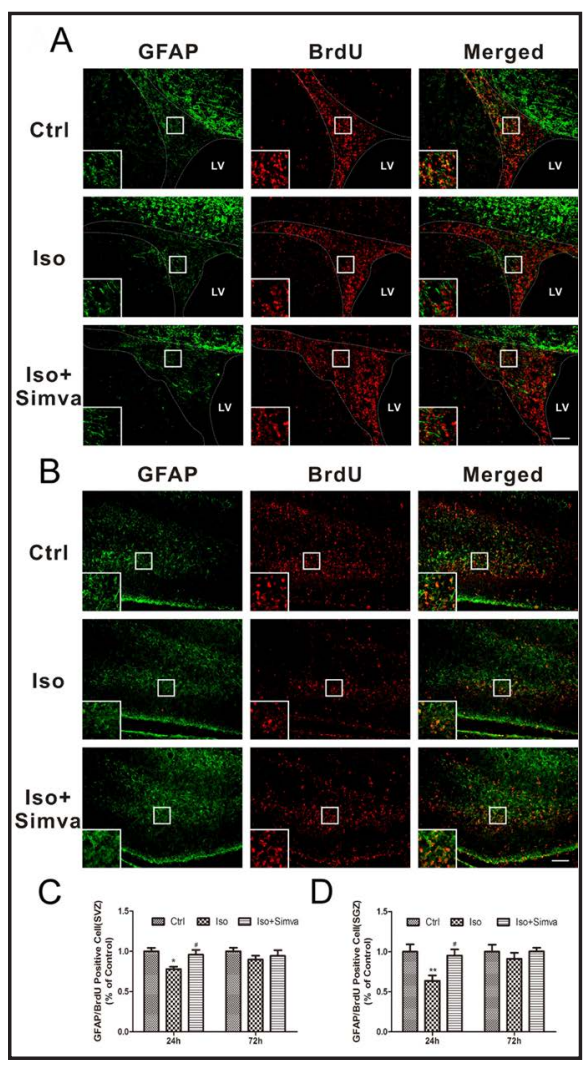

Fig. 4. The expression of cleaved caspase-3, p-Akt and p-GSK-3 $\beta$ in vivo. (A) Representative images of cleaved caspase-3 expression by western blot in the SVZ and SGZ $12 \mathrm{~h}$ after isoflurane exposure. (B) Quantitative analysis of cleaved caspase-3 expression normalized to $\beta$-actin in the SVZ and SGZ. (C) Representative images of p-Akt and p-GSK-3 $\beta$ expressions by western blot in the SVZ. (D) $(a, b)$ Quantitative analysis of p-Akt (a) and p-GSK-3 $\beta$ (b) expression normalized to $\beta$-actin in the SVZ. (E) Representative images of $\mathrm{p}$-Akt and p-GSK-3 $\beta$ expressions by western blot in the SGZ. (F) (a, b) Quantitative analysis of p-Akt (a) and p-GSK-3 $\beta$ (b) expression normalized to $\beta$-actin in the SGZ. Data were expressed as the ratio to optical density (OD) values of the corresponding controls and showed as the

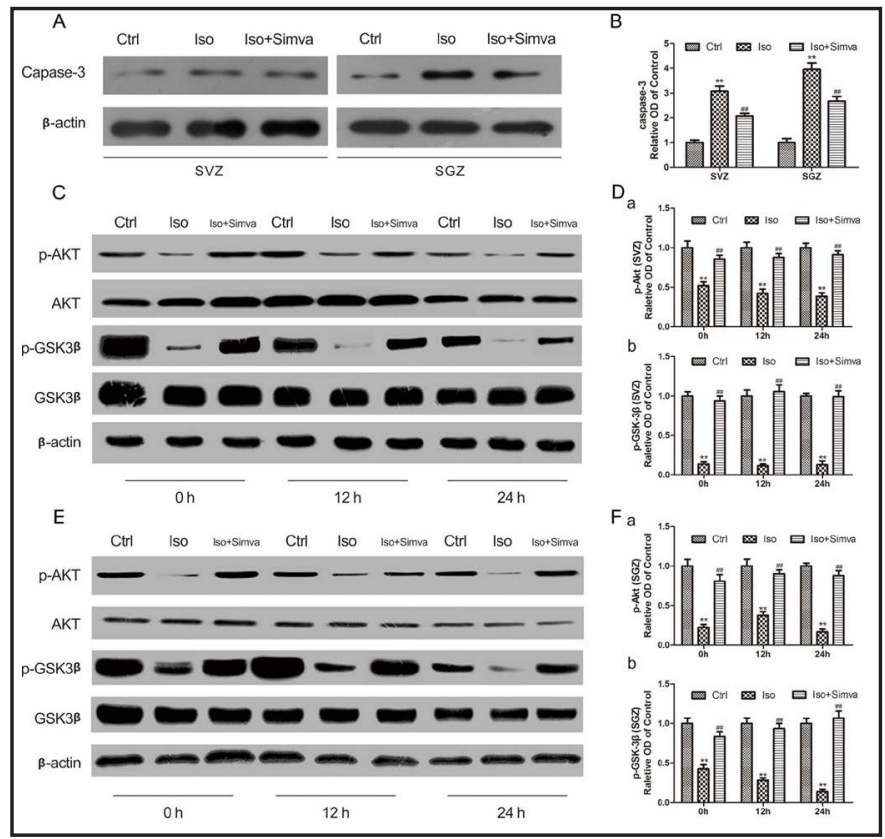
mean \pm SEM. $\mathrm{n}=5$ for each group. ${ }^{* *} \mathrm{P}<0.01$ vs. control; $\# \# \mathrm{P}<0.01$ vs. Iso group. 


\section{Cellular Physiology Cell Physiol Biochem 2018;46:618-632 and Biochemistry \begin{tabular}{c|c} 
DOI: 10.1159/000488630 & $\begin{array}{l}\text { O } 2018 \text { The Author(s). Published by S. Karger AG, Basel } \\
\text { www.karger.com/cpb }\end{array}$
\end{tabular}

Fig. 5. Identification of NSCs. (A) Representative immunofluroscence images of nestin expression in neurospheres and adherent NSCs after $3 \mathrm{~d}$ culture. (a-c) Nestin immnostaining(red) in neurospheres. (b-d) Nestin immnostaining(red) in adherent NSCs. The nuclei was stained with 4,'6-diamidino2-phenylindole(DAPI, blue). (B) Representative immunofluroscence images of cells which differentiated into neurons and astrocytes after 7 days differentiation culture. (a-d) Immunostaining of $\beta$-tubulin III(red) and GFPA (green), respectively. The nuclei was stained with DAPI(blue). Scale bars $=100 \mu \mathrm{m}$.

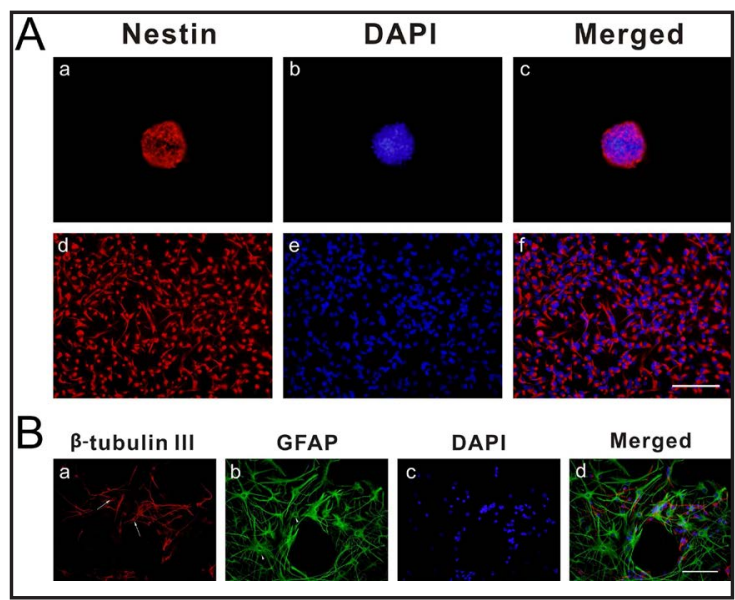

Fig. 6. The number of BrdU positive cells and the changes of NSC viability.(A) Representative immnofluorescence images of BrdU positive cells $24 \mathrm{~h}$ after isoflurane exposure in vitro. Cells were stained for BrdU (green) and PI for the nucleus (red). Preincubation with simvastatin increased the number of BrdU positive cell which was decreased significantly by isoflurane. Scale bar $=50 \mu \mathrm{m}$. (B) Quantitative analysis of BrdU positive cells at different times after isoflurane exposure. (C) Viability of NSCs in different groups. Cell viability was measured by CCK- 8 assay at 12, 24 and $48 \mathrm{~h}$ after isoflurane exposure in vitro. All data are presented as mean \pm SEM of three independent experiments. $n$ $=6$ for each group. ${ }^{* *} \mathrm{P}<0.01$ vs. control; $\# \# \mathrm{P}<0.01$ vs. Iso group. Scale bars $=50 \mu \mathrm{m}$.

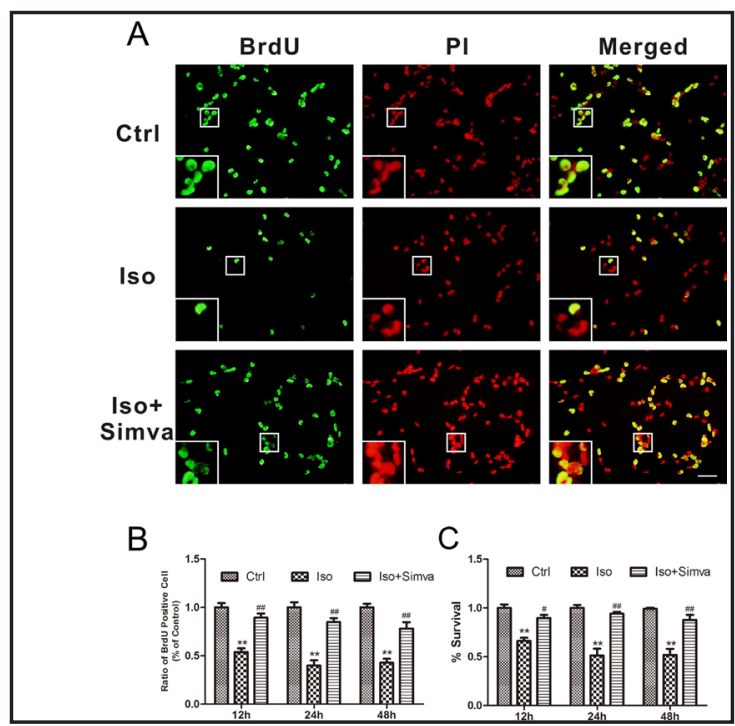

Simvastatin rescued NSC proliferation, increased cell viability and reduced NSC apoptosis following isoflurane exposure

Firstly, we determined the characteristics of cell cultures. It was found that most of cells expressed the NSC marker nestin both in suspension and adherent culture $(98.8 \pm 0.3 \%$, Fig. 5A) 3 days after seeding. Following incubated with differentiating medium for 7 days, cultured cells expressed $\beta$-tubulinШ $(24.8 \pm 2.7 \%$, Fig. 5B, arrow), a specific maker for neuron and GFAP (48.4 $\pm 1.4 \%$, Fig. 5B, arrowhead), and a specific maker for astrocytes. These results indicated that the cells cultured in the present study were NSCs.

BrdU incorporation was used to detect NSC proliferation. It was showed that isoflurane exposure decreased the number of BrdU-positive cells compared with the control. However, pretreatment with simvastatin rescued the proliferation of NSCs at 12, 24 and $48 \mathrm{~h}$ after isoflurane exposure, respectively (Fig. 6A and B).

To determine whether isoflurane induced deregulation in NSC viability, the cell viability was assessed at 12, 24 and $48 \mathrm{~h}$ after 3.4\% isoflurane exposure. It was shown that isoflurane caused a time-dependent viability decrease in NSCs, and simvastatin elicited a time-dependent viability increase in NSCs exposed to isoflurane (Fig. 6C). To detect whether simvastatin could reduce NSC apoptosis after isoflurane exposure, TUNEL staining was used to assess apoptotic NSCs at 12, 24 and $48 \mathrm{~h}$ after isoflurane exposure. Compared with the control, the number of TUNEL positive cells increased obviously after isoflurane 


\section{Cellular Physiology Cell Physiol Biochem 2018;46:618-632

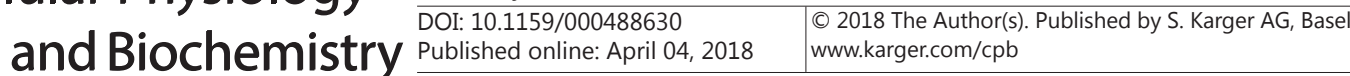

Fig. 7. The apoptosis of NSCs and the expression of the cleaved caspase- 3 , p-Akt and p-GSK-3 $\beta$ in vitro. (A) Representative fluorescence images of TUNEL positive cells $24 \mathrm{~h}$ after isoflurane exposure in vitro. Cells were stained for TUNEL (green) and DAPI for the nucleus (blue). Pre-treatment with simvastatin decreased the number of TUNEL positive cells which is increased remarkably by isoflurane exposure. (B) Quantitative analysis of TUNEL positive cells at different time after isoflurane exposure. Scale bar $=100 \mu \mathrm{m}$. All data are presented as mean \pm SEM of three independent experiments. $n=6$ for each group. (C) Quantitative analysis of cleaved caspase-3 expression normalized to $\beta$-actin in vitro. (D) Representative images of the cleaved caspase-3 expression by western blot in vitro. (E) Representative images of $\mathrm{p}$-Akt and $\mathrm{p}-\mathrm{GSK}-3 \beta$ expressions by western blot in vitro. (F) (a,b) Quantitative analysis of p-Akt (a) and p-GSK-3 $\beta$ (b) expression normalized to $\beta$-actin in vitro. Data were expressed as the ratio to $\mathrm{OD}$ values of the corresponding controls and showed as the mean \pm SEM. $n=6$ for each group. ${ }^{* *} \mathrm{P}<0.01$ vs. control; $\# \# \mathrm{P}<0.01$ vs. Iso group; $\Delta \mathrm{P}<0.05, \Delta \Delta \mathrm{P}<0.01$ vs. Iso+simva group.

exposure. Pretreatment with simvastatin reduced significantly isoflurane-induced NSC apoptosis, and this effect retained for at least 48h (Fig. 7A and B).

Western blotting was used to determine related molecules involved in isofluraneinduced apoptosis and simvastatin-elicited protection. It was found that isoflurane increased caspase-3 expression and decreased the expressions of p-Akt and p-GSK-3 $\beta$ in NSCs at 0,12 , and $24 \mathrm{~h}$ after its exposure. Pretreatment with simvastatin decreased the expression of caspase- 3 and prevented isoflurane-induced deregulation

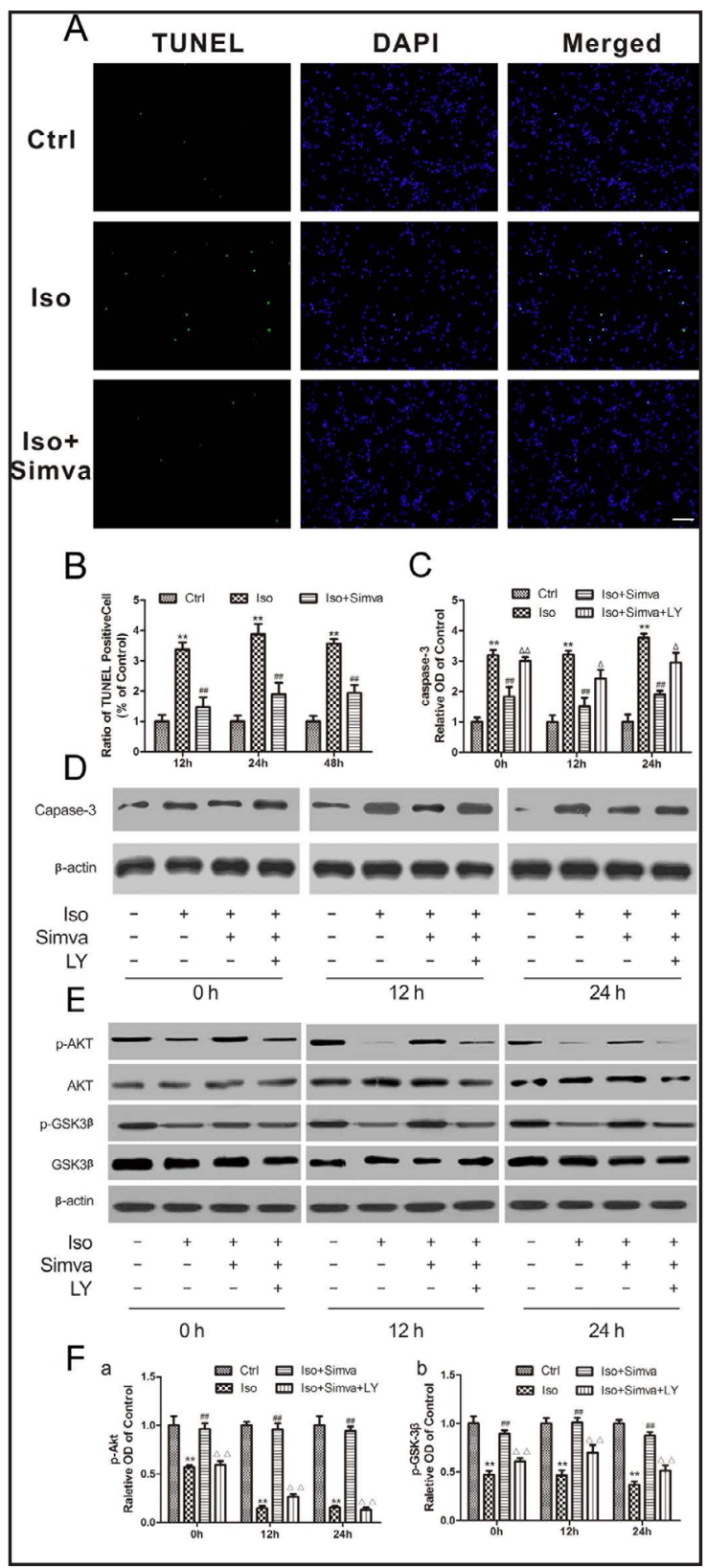
of p-Akt and p-GSK-3 $\beta$ expressions in NSCs at above time points. However, co-treatment with LY294002, an inhibitor of PI3K, reversed the effect of simvastatin on protein expressions of caspase-3, p-Akt and p-GSK-3 $\beta$ in NSCs (Fig.7C, D, E, and F). These findings suggest that simvastatin alleviated isoflurane-induced apoptosis by activating the PI3K signaling pathway.

\section{Simvastatin improved isoflurane-induced decline of learning and memory}

As showed in Fig. 8. In the place trails of MWM, no significant difference was observed among three groups in terms of swimming speed (Fig. 8B), indicating that the differences in locomotor activities were insignificant among three group. The latency to find submerge platform in the isoflurane group was longer compared to the control group at trail day 2 and 3. However, the latency was improved in simvastatin pretreatment group (Fig. 8C). In the probe test, the number of target crossing in isoflurane group decreased significantly compared with that in the control group, while the number of target crossing in simvastatin 
pretreatment group increased obviously compared to that in isoflurane group (Fig. 8D). In CFC test, the freezing time in isoflurane group decreased compared to that in the control group, this reduction was inhibited in simvastatin pretreatment group (Fig. 8E). Collectively, these data showed isoflurane exposure in neonatal rats induced impairment of learning and memory and pretreatment with simvastatin could attenuate this defect.

\section{Discussion}

In the present study, we found that pretreatment with simvastatin increased neurogenesis and improved isofluraneinduced learning and memory deficits. Pretreatment with simvastatin also reduced NSC apoptosis and increased protein expressions of $\mathrm{p}$-Akt and p-GSK-3 $\beta$ both in vitro and in vivo. Co-treatment with LY294002, a PI3K inhibitor, reversed the effect of simvastatin on NSC apoptosis and protein expressions of $\mathrm{p}$-Akt and p-GSK-

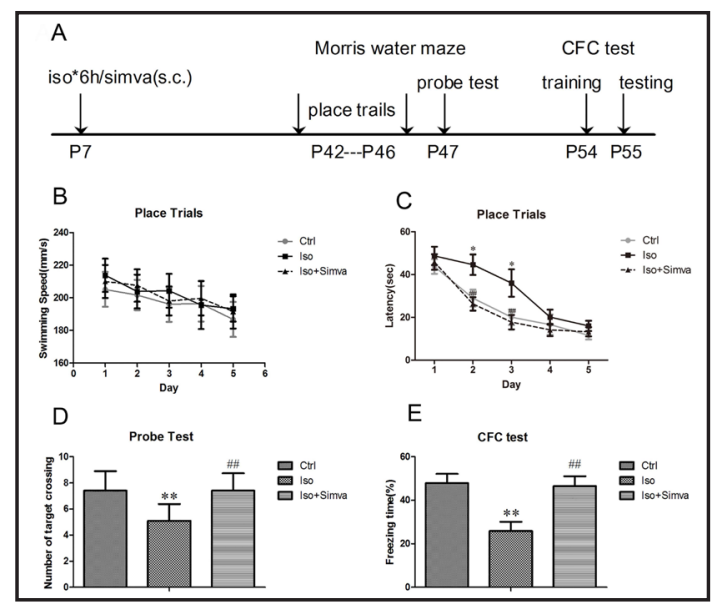

Fig. 8. The results of behavior tests. (A) The experimental schedule design for behavior study. (B, C) Comparison of swimming speed and escape latency of young rats in each group in the place trails of Morris water maze. (D) Comparison of the number of target crossings in each group in the probe test of Morris water maze. (E) Comparison of freezing time in each group in the context fear conditioning test. All data are presented as mean \pm SEM. $n=10$ for each group. ${ }^{*} \mathrm{P}<0.05,{ }^{* *} \mathrm{P}<0.01$ vs. control, $\# \# \mathrm{P}<0.01$ vs. Iso group. $3 \beta$ in vitro. These findings indicated that pretreatment with simvastatin enhanced neurogenesis and improved neurocognitive deficit by protecting NSCs from apoptosis, which was mediated by increasing $\mathrm{p}-\mathrm{Akt}$ and $\mathrm{p}$-GSK-3$\beta$ protein expressions.

Many studies have shown detrimental effects of isoflurane on neural precursor cells and in the rodent neonates and these results have not been translatable to humans. The recent pediatric anesthesia neurodevelopment assessment (PANDA) study [35] and the preliminary general anesthesia compared to spinal anesthesia (GAS) trial [36] findings showed that single, relatively brief early exposure to general anesthesia in generally healthy children is unlikely to cause clinically detectable deficits in global cognitive function or serious behavior disorders. However, the warning from the U. S. food and drug administration (FDA) stated that repeated or lengthy use of general anesthetic and sedation drugs during surgeries or procedures in children younger than 3 years or in pregnant women during their third trimester may affect the development of children's brains, indicating that anesthetic neurotoxicity is still considered a concern in humans. It is important to study the mechanisms of neurotoxicity and develop potential protective strategies for pediatric anesthesia.

Substantial neurogenesis occurs in the period of BGS, which is essential to normal brain development [37]. Exposure to anesthesia during this period may induce functional alternations in learning and memory, but not afterwards [38, 39]. The period of BGS differs from species to species in mammals. In humans, BGS period extends from about third trimester to two years after birth. In rodents, BGS lasts from birth for the first 2 weeks of life [9]. The postnatal neurogenetic process occurs in the SVZ and SGZ, which contain NSCs (B1 cells), transit-amplifying cells (C cells), and neuroblasts (A cells). B1 cells give rise to C cells, which can directly generate two neurons or divide to generate A cells that continue to proliferate [40-42], migrate and differentiate into olfactory bulb or hippocampal neurons, respectively [43]. The majority of cells in the SVZ and SGZ are C cells and A cells [44].There is a total of $4-6 \mathrm{~d}$ from the initial division of a B1 cell to the generation of postmitotic young neurons ( $\beta$-tubulin $\amalg$ positive cells) [45]. Following the division of B1 cells, the generation 
of the initial $\mathrm{C}$ cells can occur in less than a day with the following amplification of $\mathrm{C}$ cells completed in 3.5-4 d. The generation of A cells following the division of $\mathrm{C}$ cells completed in $18 \mathrm{~h}$. Theoretically, it was less than $30 \mathrm{~h}$ from A cells to postmitotic young neurons. To elucidate the cellular subpopulation by which isoflurane decreases neurogenesis, PND 7 neonatal rats and NSCs from embryonic day 18-19 rats were exposed to isoflurane according to previous methods [16, 18], and neurogenesis were assessed at $24 \mathrm{~h}$ and $72 \mathrm{~h}$ after neonatal isoflurane exposure. We found that isoflurane decreased NSC proliferation in vitro, being consistent with the early reports that isoflurane impaired NSC proliferation. Interestingly, isoflurane decreased $\beta$-tubulin $\mathrm{III}^{+} / \mathrm{BrdU}^{+}$cells both in the SVZ and SGZ at $24 \mathrm{~h}$ (corresponding to A cells to young neurons) and $72 \mathrm{~h}$ (corresponding to $\mathrm{C}$ cells to young neurons) after its exposure, indicating that isoflurane declined neurogenesis derived from $\mathrm{A}$ cells and C cells in our study. Recently, Huang et al. reported that ketamine interferes with the proliferation and differentiation of the cells in the SVZ of neonatal rats at $24 \mathrm{~h}$ and $72 \mathrm{~h}$ after its exposure [30]. However, the effects of isoflurane on NSC proliferation were attenuated by pretreatment with simvastatin both in vitro and in vivo. Pretreatment with simvastatin increased neuronal differentiation derived from A cells and C cells, which was declined by isoflurane. Moreover, pretreatment with simvastatin restored the homeostasis of $\mathrm{GFAP}^{+}$/ $\mathrm{BrdU}^{+}$cells both in the SVZ and SGZ $72 \mathrm{~h}$ after isoflurane exposure. These findings indicated that simvastatin protected neurogenesis from isoflurane-induced injury following neonatal exposure.

Exposure to isoflurane induced long-memory impairment in many studies $[14,15$, $18,46]$. In our study, isoflurane exposure on neonatal rats led to subsequent learning and memory in MWM and CFC tests, which was coincident with the previous studies $[14,18]$. However, pretreatment simvastatin attenuated the learning and memory defects induced by isoflurane exposure. While there is abundant evidence that anesthetics act to suppress neurogenesis at several different phases, substantial evidence of a causal link between inhibition of neurogenesis and any disabilities in learning behavior remains elusive. The report from Zhu and his colleague showed greater impairments in performance on an objective recognition task at 10 weeks than at 4 weeks, suggesting that progressive decline in function mirrored progressive impairments in neurogenesis [15]. One of our recent works showed that pretreatment with minocycline restored neurogenesis in SVZ and SGZ of the hippocampus, and improved adult spatial learning and memory deficits induced by ketamine exposure in neonatal rats [12]. In this study isoflurane decreased neurogenesis and impaired cognitive functions, but pretreatment with simvastatin increased neurogenesis and improved isoflurane-induced learning and memory deficits, strengthening connection between neurogenesis and cognitive dysfunction in developmental anesthetic neurotoxicity. The present finding indicated that simvastatin improved isoflurane-induced neurocognitive impairment by protecting neurogenesis in the developing brain. In the future study, more work need to be done to determine whether the neurocognitive improvement is due to longterm protection of simvastatin on neurogenesis. Whether simvastatin can mitigate isofluraneinduced neuronal apoptosis and that contributes to improvement of neurocognitive deficits also need to be determined further.

Neurogenesis is characterized by three stages: (1) cell proliferation to generate new cells; (2) cell migration in which newly-generated cells move to their final destination; and (3) cell differentiation to produce the phenotype and function of a neuron, astrocyte and oligodendrocyte [47]. The accuracy of one stage is dependent on the accuracy of the former stages [48]. Proliferation and/or survival of NSCs present one of the basic events for neurogenesis. In our study, BrdU labeling and apoptosis analysis were used to assess NSC proliferation and survival. We found that isoflurane decreased cell viability and BrdU-positive cells while increased NSC apoptosis and caspase-3 protein expression in vitro. Interestingly, pretreatment with simvastatin alleviated the above changes induced by isoflurane exposure. Although it is unknown whether increased BrdU-positive cells resulted simply from NSC proliferation or decreased cell apoptosis, pretreatment with simvastatin restored the number of nestin/BrdU double-positive cells in both the SVZ and SGZ. Considering the previous

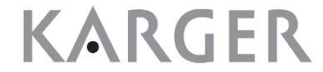




\section{Cellular Physiology Cell Physiol Biochem 2018;46:618-632

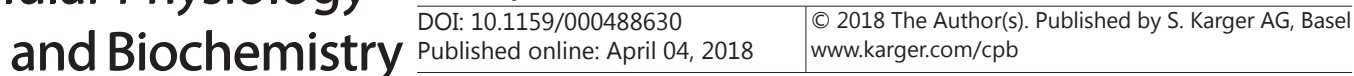 \\ Wang et al.: Developmental Neurotoxicity and Neuroprotection}

reports that isoflurane inhibited neurogenesis by promoting the apoptosis of NSCs [10, 15, $17,46,49]$, these results indicated that simvastatin protected neurogenesis by reducing NSC apoptosis.

Akt is downstream target of PI3K. The PI3K/Akt cascade has been reported to inhibit apoptosis and promote cell survival through insulin and growth factors [50, 51]. After phosphoinositide-dependent protein kinase (PDK) phosphorylating Akt-1, GSK-3 $\beta$, a serine/threonine kinase, is inhibited [52]. Studies have demonstrated that GSK-3 $\beta$ played an important role in fundamental functions of cell such as cell cycle, cytoskeletal integrity, dendritic growth, axon growth and neuronal differentiation [53, 54]. Isoflurane induced neuroapoptosis and synaptogenesis impairment by decreasing ribosomal protein S6 activity through suppression of upstream IGF-1/MEK/ERK and IGF-1/PI3K/Akt signaling [55]. Simvastatin activated the PI3K/Akt-mediated signaling pathway after experimental intracerebral hemorrhage $[23,26]$. Simvastatin increased neurogenesis through activating Akt/GSK-3 $\beta$ signaling pathway and subsequently upregulating expression of growth factors, VEGF and BDNF in the dentate gyrus of hippocampus in traumatic brain injury rats [56]. In this study, simvastatin pretreatment increased the protein levels of p-Akt and p-GSK$3 \beta$ deregulated by isoflurane and decreased the NSC apoptosis both in vitro and vivo. Cotreatment with LY294002, the inhibitor of PI3K, blocked the up-regulation of p-Akt and p-GSK-3 $\beta$ protein expressions as well as deregulation of NSC apoptosis by simvastatin, indicating that $\mathrm{PI} 3 \mathrm{~K} / \mathrm{Akt} / \mathrm{GSK}-3 \beta$ signaling pathway is involved in the neuroprotection of simvastatin against isoflurane-induced NSC apoptosis. This is similar to the findings that simvastatin played in other models $[56,57]$. Whether the protective effects of simvastatin is merely due to the increase in Akt phosphorylation or the decrease in Akt and GSK-3 $\beta$ dephosphorylation needs to be studied further.

Theoretically, a control group pretreated with simvastatin without isoflurane exposure should be designed in our study. In fact, therapeutic drugs were used just under pathological condition. It has been reported that simvastatin increase neurogenesis both under pathological and physiological condition $[58,59]$ and has no significant toxicity on neonatal rats [25]. So, we did not design a control group with simvastatin alone in the present study. In addition, we did not detect NSC differentiation in vitro, because our priority was to ivestigate whether simvastatin could restore neurogenesis and improve neurocognitive deficits following isoflurane exposure. The further study should be done to investigate whether simvastatin alleviate the effect of isoflurane on NSC differentiation in vitro.

\section{Conclusion}

In summary, simvastatin, by regulating Akt/GSK-3 $\beta$ signaling pathway prevents neurogenetic damage and late negative neurocognitive consequences after isoflurane exposure in neonates. As a protecting agent, simvastatin has gained wide acceptance in cardiovascular and neurological disease therapy. Therefore, this study recommends it as a highly appealing treatment for isoflurane neurotoxicity. However, the underlying mechanisms of its protective effects and whether it is beneficial in reducing neurotoxicity in other cellular type such as neurons, astrocytes etc caused by other anesthetic agents need to be further investigated.

\section{Acknowledgements}

This work was supported by the National Natural Science Foundation of China (81071071, 81171247), Key Science and Technology Innovation Team of Shaanxi Province (2014KCT-22) and Science and Technology Development Project of Shaanxi Province grants (2013KTCL03-09). We thank Jian-shui Zhang and Kun Zhu for their assistance with collecting behavioral data. We would also like to thank Prof. Malgorzata Garstka for reading this manuscript. 


\section{Cellular Physiology Cell Physiol Biochem 2018;46:618-632 \begin{tabular}{l|l} 
and Biochemistry Published 10.1159/000488630 & $\begin{array}{l}\text { C } 2018 \text { The Author(s). Published by S. Karger AG, Basel } \\
\text { www.karger.com/cpb }\end{array}$
\end{tabular}}

Wang et al.: Developmental Neurotoxicity and Neuroprotection

Disclosure Statement

The authors declare that there are no conflicts of interest associated with this study.

\section{References}

-1 Creeley C, Dikranian K, Dissen G, Martin L, Olney J, Brambrink A: Propofol-induced apoptosis of neurones and oligodendrocytes in fetal and neonatal rhesus macaque brain. Br J Anaesth 2013;110 Suppl 1:i29-i38.

-2 Ramage TM, Chang FL, Shih J, Alvi RS, Quitoriano GR, Rau V, Barbour KC, Elphick SA, Kong CL, Tantoco NK, Ben-Tzur D, Kang H, McCreery MS, Huang P, Park A, Uy J, Rossi MJ, Zhao C, Di Geronimo RT, Stratmann G, Sall JW: Distinct long-term neurocognitive outcomes after equipotent sevoflurane or isoflurane anaesthesia in immature rats. Br J Anaesth 2013;110 Suppl 1:i39-i46.

-3 Lee BH, Chan JT, Hazarika O, Vutskits L, Sall JW: Early exposure to volatile anesthetics impairs long-term associative learning and recognition memory. PLoS One 2014;9:e105340.

4 DiMaggio C, Sun LS, Li G: Early childhood exposure to anesthesia and risk of developmental and behavioral disorders in a sibling birth cohort. Anesth Analg 2011;113:1143-1151.

5 Flick RP, Katusic SK, Colligan RC, Wilder RT, Voigt RG, Olson MD, Sprung J, Weaver AL, Schroeder DR, Warner DO: Cognitive and behavioral outcomes after early exposure to anesthesia and surgery. Pediatrics 2011;128:e1053-e1061.

6 Ing C, DiMaggio C, Whitehouse A, M KH, Brady J, Davidson A, A JW, Li G, L SS: Long-term differences in language and cognitive function after childhood exposure to anesthesia. Pediatrics 2012;130:e476-e485.

7 Bong CL, Allen JC, Kim JT: The effects of exposure to general anesthesia in infancy on academic performance at age 12 ANESTH ANALG 2013;117:1419-1428.

8 Block RI, Thomas JJ, Bayman EO, Choi JY, Kimble KK, Todd MM: Are anesthesia and surgery during infancy associated with altered academic performance during childhood? Anesthesiology 2012;117:494-503.

-9 Ponten E, Viberg H, Gordh T, Eriksson P, Fredriksson A: Clonidine abolishes the adverse effects on apoptosis and behaviour after neonatal ketamine exposure in mice. Acta Anaesthesiol Scand 2012;56:1058-1065.

10 Bai X, Twaroski D, Bosnjak ZJ: Modeling anesthetic developmental neurotoxicity using human stem cells. Semin Cardiothorac Vasc Anesth 2013;17:276-287.

$>11$ Kang E, Berg DA, Furmanski O, Jackson WM, Ryu YK, Gray CD, Mintz CD: Neurogenesis and developmental anesthetic neurotoxicity. Neurotoxicol Teratol 2017;60:33-39.

12 Lu Y, Giri PK, Lei S, Zheng J, Li W, Wang N, Chen X, Lu H, Zuo Z, Liu Y, Zhang P: Pretreatment with minocycline restores neurogenesis in the subventricular zone and subgranular zone of the hippocampus after ketamine exposure in neonatal rats. Neuroscience 2017;352:144-154.

-13 Istaphanous GK, Howard J, Nan X, Hughes EA, McCann JC, McAuliffe JJ, Danzer SC, Loepke AW: Comparison of the neuroapoptotic properties of equipotent anesthetic concentrations of desflurane, isoflurane, or sevoflurane in neonatal mice. Anesthesiology 2011;114:578-587.

$>14$ Tao G, Xue Q, Luo Y, Li G, Xia Y, Yu B: Isoflurane is more deleterious to developing brain than desflurane: The role of the Akt/GSK3beta signaling pathway. Biomed Res Int 2016;2016:7919640.

-15 Zhu C, Gao J, Karlsson N, Li Q, Zhang Y, Huang Z, Li H, Kuhn HG, Blomgren K: Isoflurane anesthesia induced persistent, progressive memory impairment, caused a loss of neural stem cells, and reduced neurogenesis in young, but not adult, rodents. J Cereb Blood Flow Metab 2010;30:1017-1030.

-16 Sall JW, Stratmann G, Leong J, McKleroy W, Mason D, Shenoy S, Pleasure SJ, Bickler PE: Isoflurane inhibits growth but does not cause cell death in hippocampal neural precursor cells grown in culture. Anesthesiology 2009;110:826-833.

17 Culley DJ, Boyd JD, Palanisamy A, Xie Z, Kojima K, Vacanti CA, Tanzi RE, Crosby G: Isoflurane decreases selfrenewal capacity of rat cultured neural stem cells. Anesthesiology 2011;115:754-763.

18 Stratmann G, Sall JW, May LD, Bell JS, Magnusson KR, Rau V, Visrodia KH, Alvi RS, Ku B, Lee MT, Dai R: Isoflurane differentially affects neurogenesis and long-term neurocognitive function in 60-day-old and 7-day-old rats. Anesthesiology 2009;110:834-848.

19 Balduini W, De Angelis V, Mazzoni E, Cimino M: Simvastatin protects against long-lasting behavioral and morphological consequences of neonatal hypoxic/ischemic brain injury. Stroke 2001;32:2185-2191. 


\section{Cellular Physiology Cell Physiol Biochem 2018;46:618-632

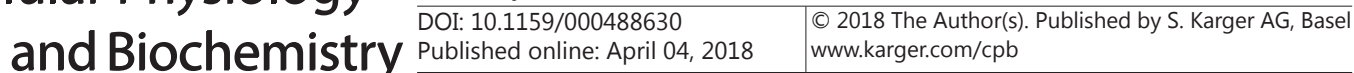

Wang et al.: Developmental Neurotoxicity and Neuroprotection

20 Xie C, Cong D, Wang X, Wang Y, Liang H, Zhang X, Huang Q: The effect of simvastatin treatment on proliferation and differentiation of neural stem cells after traumatic brain injury. Brain Res 2015;1602:1-8.

-21 Karki K, Knight RA, Han Y, Yang D, Zhang J, Ledbetter KA, Chopp M, Seyfried DM: Simvastatin and atorvastatin improve neurological outcome after experimental intracerebral hemorrhage. Stroke 2009;40:3384-3389.

-22 Lynch JR, Wang H, McGirt MJ, Floyd J, Friedman AH, Coon AL, Blessing R, Alexander MJ, Graffagnino C, Warner DS, Laskowitz DT: Simvastatin reduces vasospasm after aneurysmal subarachnoid hemorrhage: Results of a pilot randomized clinical trial. Stroke 2005;36:2024-2026.

-23 Cheng G, Chunlei W, Pei W, Zhen L, Xiangzhen L: Simvastatin activates Akt/glycogen synthase kinase-3beta signal and inhibits caspase- 3 activation after experimental subarachnoid hemorrhage. Vascul Pharmacol 2010;52:77-83.

24 Li A, Lv S, Yu Z, Zhang Y, Ma H, Zhao H, Piao H, Li S, Zhang N, Sun C: Simvastatin attenuates hypomyelination induced by hypoxia-ischemia in neonatal rats. Neurol Res 2010;32:945-952.

-25 Wong MJ, Kantores C, Ivanovska J, Jain A, Jankov RP: Simvastatin prevents and reverses chronic pulmonary hypertension in newborn rats via pleiotropic inhibition of RhoA signaling. Am J Physiol Lung Cell Mol Physiol 2016;311:L985-L999.

26 Yang D, Han Y, Zhang J, Chopp M, Seyfried DM: Statins enhance expression of growth factors and activate the PI3K/Akt-mediated signaling pathway after experimental intracerebral hemorrhage. World J Neurosci 2012;2:74-80.

27 Reynolds BA, Weiss S: Generation of neurons and astrocytes from isolated cells of the adult mammalian central nervous system. Science 1992;255:1707-1710.

28 Gao K, Shen Z, Yuan Y, Han D, Song C, Guo Y, Mei X: Simvastatin inhibits neural cell apoptosis and promotes locomotor recovery via activation of Wnt/beta-catenin signaling pathway after spinal cord injury. J Neurochem 2016;138:139-149.

29 Kramer J, Bartsch M, Krug D, Klinger M, Nitschke M, Rohwedel J: Simvastatin modulates mouse embryonic stem cell-derived chondrogenesis in vitro. Toxicol In vitro 2012;26:1170-1176.

30 Huang H, Liu L, Li B, Zhao PP, Xu CM, Zhu YZ, Zhou CH, Wu YQ: Ketamine interferes with the proliferation and differentiation of neural stem cells in the subventricular zone of neonatal rats. Cell Physiol Biochem 2015;35:315-325.

-31 Shen X, Dong Y, Xu Z, Wang H, Miao C, Soriano SG, Sun D, Baxter MG, Zhang Y, Xie Z: Selective anesthesiainduced neuroinflammation in developing mouse brain and cognitive impairment. Anesthesiology 2013;118:502-515.

-32 Xu Z, Dong Y, Wang H, Culley DJ, Marcantonio ER, Crosby G, Tanzi RE, Zhang Y, Xie Z: Age-dependent postoperative cognitive impairment and Alzheimer-related neuropathology in mice. Sci Rep 2014;4:3766.

-33 Zhong T, Ren F, Huang CS, Zou WY, Yang Y, Pan YD, Sun B, Wang E, Guo QL: Swimming exercise ameliorates neurocognitive impairment induced by neonatal exposure to isoflurane and enhances hippocampal histone acetylation in mice. Neuroscience 2016;316:378-388.

-34 Tamm C, Ceccatelli S: Mechanistic insight into neurotoxicity induced by developmental insults. Biochem Biophys Res Commun 2017;482:408-418.

-35 Sun LS, Li G, Miller TL, Salorio C, Byrne MW, Bellinger DC, Ing C, Park R, Radcliffe J, Hays SR, DiMaggio CJ, Cooper TJ, Rauh V, Maxwell LG, Youn A, McGowan FX: Association between a single general anesthesia exposure before age 36 months and neurocognitive outcomes in later childhood. JAMA 2016;315:23122320.

-36 Davidson AJ, Disma N, de Graaff JC, Withington DE, Dorris L, Bell G, Stargatt R, Bellinger DC, Schuster T, Arnup SJ, Hardy P, Hunt RW, Takagi MJ, Giribaldi G, Hartmann PL, Salvo I, Morton NS, von Ungern SB, Locatelli BG, Wilton N, Lynn A, Thomas JJ, Polaner D, Bagshaw O, Szmuk P, Absalom AR, Frawley G, Berde C, Ormond GD, Marmor J, McCann ME: Neurodevelopmental outcome at 2 years of age after general anaesthesia and awake-regional anaesthesia in infancy (GAS): An international multicentre, randomised controlled trial. Lancet 2016;387:239-250.

-37 Muramatsu R, Ikegaya Y, Matsuki N, Koyama R: Neonatally born granule cells numerically dominate adult mice dentate gyrus. Neuroscience 2007;148:593-598.

-38 Slikker WJ, Zou X, Hotchkiss CE, Divine RL, Sadovova N, Twaddle NC, Doerge DR, Scallet AC, Patterson TA, Hanig JP, Paule MG, Wang C: Ketamine-induced neuronal cell death in the perinatal rhesus monkey. Toxicol Sci 2007;98:145-158. 


\section{Cellular Physiology Cell Physiol Biochem 2018;46:618-632

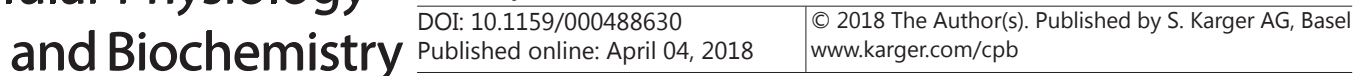

Wang et al.: Developmental Neurotoxicity and Neuroprotection

-39 Hansen HH, Briem T, Dzietko M, Sifringer M, Voss A, Rzeski W, Zdzisinska B, Thor F, Heumann R, Stepulak A, Bittigau P, Ikonomidou C: Mechanisms leading to disseminated apoptosis following NMDA receptor blockade in the developing rat brain. Neurobiol Dis 2004;16:440-453.

40 Luskin MB, Zigova T, Soteres BJ, Stewart RR: Neuronal progenitor cells derived from the anterior subventricular zone of the neonatal rat forebrain continue to proliferate in vitro and express a neuronal phenotype. Mol Cell Neurosci 1997;8:351-366.

-41 Menezes JR, Smith CM, Nelson KC, Luskin MB: The division of neuronal progenitor cells during migration in the neonatal mammalian forebrain. Mol Cell Neurosci 1995;6:496-508.

-42 Lois C, Garcia-Verdugo JM, Alvarez-Buylla A: Chain migration of neuronal precursors. Science 1996;271:978-981.

43 Guerout N, Li X, Barnabe-Heider F: Cell fate control in the developing central nervous system. Exp Cell Res 2014;321:77-83.

44 Parras CM, Galli R, Britz O, Soares S, Galichet C, Battiste J, Johnson JE, Nakafuku M, Vescovi A, Guillemot F: Mash1 specifies neurons and oligodendrocytes in the postnatal brain. EMBO J 2004;23:4495-4505.

45 Ponti G, Obernier K, Guinto C, Jose L, Bonfanti L, Alvarez-Buylla A: Cell cycle and lineage progression of neural progenitors in the ventricular-subventricular zones of adult mice. Proc Natl Acad Sci U S A 2013;110:E1045-E1054.

46 Hou L, Liu T, Wang J: Isoflurane suppresses the self-renewal of normal mouse neural stem cells in a p53dependent manner by activating the Lkb1-p53-p21 signalling pathway. Mol Med Rep 2015;12:7412-7418.

47 Zhao C, Deng W, Gage FH: Mechanisms and functional implications of adult neurogenesis. Cell 2008;132:645-660.

-48 Stiles J, Jernigan TL: The basics of brain development. Neuropsychol Rev 2010;20:327-348.

49 Zhang Y, Pan C, Wu X, Dong Y, Culley DJ, Crosby G, Li T, Xie Z: Different effects of anesthetic isoflurane on caspase-3 activation and cytosol cytochrome c levels between mice neural progenitor cells and neurons. Front Cell Neurosci 2014;8:14.

50 Chalecka-Franaszek E, Chuang DM: Lithium activates the serine/threonine kinase Akt-1 and suppresses glutamate-induced inhibition of Akt-1 activity in neurons. Proc Natl Acad Sci U S A 1999;96:8745-8750.

-51 Franke TF, Yang SI, Chan TO, Datta K, Kazlauskas A, Morrison DK, Kaplan DR, Tsichlis PN: The protein kinase encoded by the Akt proto-oncogene is a target of the PDGF-activated phosphatidylinositol 3-kinase. Cell 1995;81:727-736.

52 Hur EM, Zhou FQ: GSK3 signalling in neural development. Nat Rev Neurosci 2010;11:539-551.

53 Fuchs C, Trazzi S, Torricella R, Viggiano R, De Franceschi M, Amendola E, Gross C, Calza L, Bartesaghi R, Ciani E: Loss of CDKL5 impairs survival and dendritic growth of newborn neurons by altering AKT/GSK3beta signaling. Neurobiol Dis 2014;70:53-68.

54 Li CL, Sathyamurthy A, Oldenborg A, Tank D, Ramanan N: SRF phosphorylation by glycogen synthase kinase-3 promotes axon growth in hippocampal neurons. J NeurosciI 2014;34:4027-4042.

55 Li G, Xue Q Luo Y, Hu X, Yu B: S6 inhibition contributes to isoflurane neurotoxicity in the developing brain. Toxicol Lett 2015;233:102-113.

-56 Wu H, Lu D, Jiang H, Xiong Y, Qu C, Li B, Mahmood A, Zhou D, Chopp M: Simvastatin-mediated upregulation of VEGF and BDNF, activation of the PI3K/Akt pathway, and increase of neurogenesis are associated with therapeutic improvement after traumatic brain injury. J Neurotrauma 2008;25:130-139.

-57 Xu YQ, Long L, Yan JQ, Wei L, Pan MQ, Gao HM, Zhou P, Liu M, Zhu CS, Tang BS, Wang Q: Simvastatin induces neuroprotection in 6-OHDA-lesioned PC12 via the PI3K/AKT/caspase 3 pathway and anti-inflammatory responses. CNS Neurosci Ther 2013;19:170-177.

58 Huang C, Fu XH, Zhou D, Li JM: The role of Wnt/beta-Catenin signaling pathway in disrupted hippocampal neurogenesis of temporal lobe epilepsy: A potential therapeutic target? Neurochem Res 2015;40:13191332.

59 Wang C, Chen T, Li G, Zhou L, Sha S, Chen L: Simvastatin prevents beta-amyloid(25-35)-impaired neurogenesis in hippocampal dentate gyrus through alpha7nAChR-dependent cascading PI3K-Akt and increasing BDNF via reduction of farnesyl pyrophosphate. Neuropharmacology 2015;97:122-132. 